\title{
ИССЛЕДОВАНИЕ КУЛЬТУРНОЙ ИДЕНТИЧНОСТИ КИТАЙСКИХ МИГРАНТОВ В РОССИИ
}

\section{STUDY OF CULTURAL IDENTITY OF CHINESE MIGRANTS IN RUSSIA}

Jiang Dan

Summary: Culture is a very important factor for the social integration of immigrants. Based on this starting point, this paper discusses how cultural values affect the social integration of the Chinese in Russia. From the perspective of cultural dimension theory, this paper expounds the similarities and differences in cultural values between China and Russia. The influence of cultural values on the social integration of Chinese and overseas Chinese is reflected in the mutual recognition of the two sides, as well as the willingness and legal awareness of Chinese to participate in politics, work and life, marriage and family life, social networks and many other aspects. Research shows that both cultural differences and similarities may have both advantages and disadvantages.

Keywords: Russian, Chinese, cultural identity.
Д войная культурная идентичность китайских мигрантов в России носит одновременно инструментальный и избирательный характер и характесложным многообразием. Двойная культурная идентичность китайских мигрантов в России характеризуется в основном смешанными характеристиками. Индивидуальные различия проявляются не только между разными группами и поколениями, но и внутри одной и той же группы. Это результат формирования микроэлементов семейной среды, опыта роста и индивидуального характера.

Культурная идентичность китайских эмигрантов в России всегда была предметом озабоченности ученых. До сих пор научные круги и общество сходятся во мнении о том, что первое поколение китайских эмигрантов в России имеет более сильную культурную идентичность или двойную культурную идентичность, в то время как новые поколения китайского происхождения, как правило, имеют двойную культурную идентичность или культурную идентичность страны пребывания. Таким образом, двойная культурная идентичность является наиболее распространенным и распространенным типом самобытности китайских мигрантов в России. Однако, в

\author{
Цзян Дань \\ Аспирант, Забайкальский государственный \\ университет; доцент, Хэйхэский университет Китая \\ waiyuxijiangdan@163.com
}

Аннотация: Культура - очень важный фактор, влияющий на социальную интеграцию мигрантов. Исходя из этой отправной точки, в данной статье исследуется, как культурные ценности влияют на реализацию социальной интеграции китайских мигрантов в России. В данной статье проводится анализ с точки зрения теории культурного измерения и излагается близость и сходство культурных ценностей между Китаем и Россией. Влияние культурных ценностей на реализацию социальной интеграции китайцев, проживающих в России, находит свое отражение во взаимном признании двух народов, а также в готовности китайского народа участвовать в политике и правосознании, работе и жизни, браке и семейная жизнь, социальные сети и многое другое. Исследования показали, что как культурные различия, так и сходства могут иметь как плюсы, так и минусы, и их нельзя обобщать.

Ключевые слова: Россия, китайские мигранты, культурная идентичность.

настоящее время в национальных научных кругах, попрежнему, ощущается нехватка углубленных исследований по вопросу о двойной культурной идентичности китайских эмигрантов в России. Так, автор, основываясь на данных полевого обследования китайских эмигрантов в России, в сочетании с социологией, культурной психологии и антропологией, пытается на микроуровне глубже изучить основные черты двойной культурной идентичности китайцев в России.

\section{1. Основная причина и ситуашия китайских эмигрантов в России}

Китайские эмигранты в России являются связующим звеном и местом в российско-китайских отношениях, проводником социально-экономического развития Китая и России, распространителями превосходной китайской и русской национальных культур и завершением китайско-российской дружбы.

Китайские эмигранты в России являются свидетелем и участниками сообщества судьбы человека, являются важной силой китайской мечты о великом возрождении китайской нации, являются одной из самых ярких стра-

Данная статья публикуется в рамках научно-исследовательского проекта основного операционного расхода вузов в провинции Хэйлунцзян 2018 г. на тему «Изучение изменений истории и нынешнего состояния китайских мигрантов на фоне районов в России» Проект: 2018-KYYWF-1283 
ниц в истории эмиграции Китая.

Как две большие территориальные державы с большими границами, Китай и Россия имеют сложные отношения. Вступив в 21 век, Китай и Россия установили стратегическое партнерство сотрудничества, и постоянно растет число китайцев в Россию. Экономическая и культурная деятельность китайских мигрантов приобретает более современные характеристики. После распада Советского Союза его экономическое строительство сильно пострадало, особенно, под влиянием глобального экономического кризиса и политики давления со стороны США, совокупные национальные силы России постепенно приближались к упадку с пика, за постепенным экономическим спадом, подчеркивая серьезную социальную проблему, а именно отрицательный рост населения. В настоящее время, после реформ и открытости соседнего Китая, внутренняя экономика развивается в хорошей ситуации, численность населения Китая и напряженная обстановка в сфере занятости вынуждают людей искать новые возможности для развития в мире.

Поскольку отношения сотрудничества России и Китая, и особенно, дальневосточный регион России граничит с северо-восточным регионом Китая, крупные города Дальнего Востока России стали для китайцев хорошим местом, где можно получить выгоду от вложения денежных средств, и местом, к которому стремятся китайские эмигранты. В начале 90 - х годов прошлого века, некоторые приграничные жители районы Китая и России, постепенно отправились в Россию для работы, сельского хозяйства, бизнеса. В настоящее время китайские эмигранты играют важную роль, став социальной группой, которую нельзя игнорировать в российском обществе.

В настоящее время в России проживает большое количество китайских мигрантов с широким распространением, широким кругом занятий и разным уровнем образования. Они условно разделены на пять частей:

- во-первых, китайские эмигранты, приехавшие в советский период, и их потомки;

- во-вторых, люди, которые в частном порядке бежали из страны во время «четырех Цин» и ранней культурной революции;

- в-третьих, китайские бизнесмены, китайские рабочие и фермеры, которые уехали в Россию добывать золото во время реформ и открытости;

- в-четвертых - это китайцы, которые остались нелегально;

- в-пятых, государственные служащие, отправленные отечественными предприятиями и учреждениями в Россию для долгосрочной работы.

\section{2. Выражение культурной иментичности китайских мигрантов в России}

Специалисты по межкультурной психологии утверждают, что двойственная культурная идентичность мигрантов в основном состоит из двух типов: смешанных и взаимозаменяемых. Согласно исследованиям, проведенным Фини и другими, лица, принадлежащие к смешанным культурам, воспринимают свою двойную культурную идентичность, считают себя равными с этнической и культурной идентичностью и гордятся своей этнической культурой. Они считают, что этнические и основные культуры, хотя и отличаются друг от друга, не противоречат друг другу. В то же время сторонники альтернативной культурной идентичности сталкиваются с трудностями в том, что касается одновременного существования двух культур, которые характеризуются значительными различиями и противоречиями в их этнической культуре и основных культурах. Китайские эмигранты, преследуя иные цели, покидают свою родину в Россию, чтобы приспособиться к чужим обстоятельствам, не только изменить быт, образ общения, но и познакомиться с мыслями, институциональными обычаями и т.д.

1) Проявление культурной идентичности в образе жизни

Китайцы приехали в Россию, им нужно не только работать, они ещё должны адаптироваться к жизни здесь. Россия и наша страна имеют много различий в природной среде, социально-экономических условиях, образе жизни людей и так далее. После многих лет тяжелой работы мигранты прошли путь от удивления и непонимания к постепенному принятию и интеграции с ними, чтобы еще больше обогатить свою жизнь. Китайские мигранты больше внимания уделяют питанию, всегда была идея «народ считает пищу своим небом». А русская кухня значительно отличается от китайской кухни, которую китайцы уже привыкли.

Но в ходе полевого исследования, проведенного автором, выяснилось, что китайцы не испытывают проблем в этой области. В начале входа в Россию, некоторые не приспособлены к русской кухне, но китайцы с северо-востока Китая более знакомы с русской едой и могут быстро ее принять. После привычки в еде они обнаружат, что русская еда более питательна и разумна в энергоснабжение, которое также хорошо соответствует потребностям жизни в России. Помимо отождествления себя с едой, помимо работы и учебы, китайские мигранты также испытывают различные «русские» развлечения на досуге, такие как посещение книжных магазинов, посещение выставок живописи и барбекю в дикой природе, что дает русское влияние и влюбляется в спорт. 
2) Проявление культурной идентичности в языковой адаптации

Языковая адаптация - важнейшее звено процесса китайской идентичности в русской культуре. За исключением китайских студентов, большинство китайцев, которые приезжают в Россию, занимаются торговлей. Большинство из них не знают русского языка. Въехав в Россию, они используют свои собственные методы изучения языка, как практической деятельности. А у тех есть базовая российская основа, после въезда в Россию, им также необходимо продолжить обучение и самосовершенствование. После многих лет жизни уровень русского языка китайских мигрантов значительно улучшился. Они могут в основном удовлетворять свои потребности в работе и жизни, но достичь уровня родного языка практически невозможно. Поэтому большинство людей считает, что русский язык - это инструмент, который редко преследует и отражает собственную красоту.

3) Проявление культурной идентичности в праздниках и обычаях

Праздник - свидетельство национальной культуры. Для китайских мигрантов в России участие в зарубежных фестивалях может быть вызвано культурными первопроходцами и любопытством, но долгосрочное участие в определенной степени позволит адаптироваться и идентифицировать себя с культурой. В ходе расследований было обнаружено, что многие китайские мигранты в России активно участвовали в деятельности по созданию поселений, считая, что это была хорошая возможность сблизиться с русскими и понять слова русских, в то время как некоторые другие сказали, что для них фестиваль просто праздник. Для этих людей главным фактором, определяющим, будут ли они участвовать в российских фестивалях или нет, являются религиозные факторы. Большинство китайцев в России не понимают русскую религию и не могут понять особого значения религиозных праздников. Обычно они не отвергают однозначно религиозные праздники, такие как Пасха и Рождество, но держатся на определенной дистанции. Некоторые китайцы считают, что лучше относиться к праздникам с осторожностью, если они не имеют четкого представления о культуре, например о значении фестивалей и фольклорных табу. Потому что, если вы будете слепо участвовать, это может иметь неприятные последствия и разрушить дружбу между друзьями.

\section{3. Способ, которым китайские мигранты в России воп^ошают свою культурную иАентичность}

1) Китайские общества

После распада Советского союза, с увеличением числа китайских мигрантов в России, они создали ассоциации в соответствии с географическими, профессиональными, родственными и кровными узами, структура и характеристики ассоциации китайских эмигрантов существенно изменились. В последние годы ассоциации китайских мигрантов в России, такие, как торговая палата Китая, женская федерация, ассоциация китайских мигрантов, ассоциация китайских соотечественников провинции Фуцзянь, обувная ассоциация Вэньчжоу, ассоциация боевых искусств и так далее, стали более разнообразными. Так, например, в Хабаровске есть ассоциация хабаровских мигрантов (1993 год), торговая палата Китая и России (1999 год), ассоциация иркутских китайских мигрантов (1998 год), во Владивостоке есть торгово-промышленная ассоциация китайских китайцев, а также ассоциация китайских мигрантов в СанктПетербурге.

Работа этих китайских ассоциаций является обязательной и не требует никакой компенсации. Их работа разделена на две основные направления: оказание безвозмездной помощи китайцам в России и оказание помощи уязвимым группам населения России в качестве китайских добровольцев. Например, для детей из местных сиротских приютов организуются новогодние мероприятия, отправляются в дома престарелых, школы-интернаты, передаются в дар русско-китайским материалам. Кроме того, они поначалу поддерживали связь и сотрудничество с общественными организациями, добровольцами вузов России, в ходе которых они способствовали постепенному формированию образа китайских граждан в России, передавали доброжелательные чувства китайского народа и поддерживали отношения между народами двух стран. Благодаря объединению китайцев в России китайцы ускорили адаптацию к жизни в России и к русской культуре. С самого начала Китаец может быть в той же языковой и культурной организации общества, обмениваться с соотечественниками опытом и извлеченными уроками в процессе социальной адаптации, можно сказать, что «культурная идентичность» является ускоренным этапом.

В то же время, общественные организации благодаря эффекту коллектива позволяют более оперативно и широко распространять российскую культуру среди китайских мигрантов в России. Например, Федерация студентов московского университета, часто на коллективной основе, принимает участие в культурных мероприятиях посольства Китая в Российской Федерации, а также оказывает содействие в организации конкурса по изучению русского языка и культуры для китайских студентов-иностранцев, будь то в ходе экскурсий или конкурсов, делает китайских мигрантов в России более глубокими знаниями о культуре России. 


\section{2) $\mathrm{CMU}$}

Среди первых китайских мигрантов в России у многих были языковые барьеры, трудности в контакте с внешним миром и неудобства в жизни и работе. С увеличением числа китайских мигрантов в России распространение информации и обмен ею стали острой потребностью, поэтому появились китайские самостоятельные газеты. С развитием Интернет технологий и широким использованием мобильных электронных устройств появилось множество формы стали более разнообразными. Появились СМИ с более насыщенным содержанием, такие как традиционные бумажные СМИ «Китайско-русский вестник», «Дорожные новости», «Китайская Русская Таймс», «Вечерние новости Москвы», «Русский дракон», «Новости Альянса», Китайско-российская информационная газета и т.д. Эти СМИ предоставили качественную и своевременную информацию для китайских мигрантов в России и приложили большие усилия для распространения двусторонней культуры Китая и России. Китайские читатели также понимают официальные новости из Ки- тай и России. Последние события в российском обществе очень помогают им понять и принять российское общество и культуру и помогают им быстро интегрироваться в российское общество и жизнь.

С развитием времени процесс китайской культурной идентичности в России претерпел новые изменения, которые в основном проявляются в диверсификации каналов адаптации и уменьшении сложности адаптации. Для содействия дружеским обменам между двумя народами, китайские мигранты в России уделяют больше внимания изучению языка, чтобы преодолеть барьеры в межличностном общении и культурном взаимопонимании, сталкиваясь с культурными конфликтами, искать точки соприкосновения, сохраняя при этом различия, дорожить общностью между китайской и русской культурами, в культурной психологии, избавляться от оковы мышления, укрепляют международное видение и сталкиваются с культурой с более уверенным и спокойным отношение способствует долговременной дружбе между китайским и российским народами.

\section{ЛИТЕРАТУРА}

1. Иностранные китайцы в России вынуждены вернуться в Китай: декларация: 7-е изд., 16 марта 1931 г. Цитируется Бай Цзюнь Цзюньчжә.

2. Хань Лин, Исследование китайской культурной идентичности иностранных китайских студентов с точки зрения межкультурной адаптации, 2021(01).

(C) Цзян Дань (waiyuxijiangdan@163.com).

Журнал «Современная наука: актуальные проблемы теории и практики»

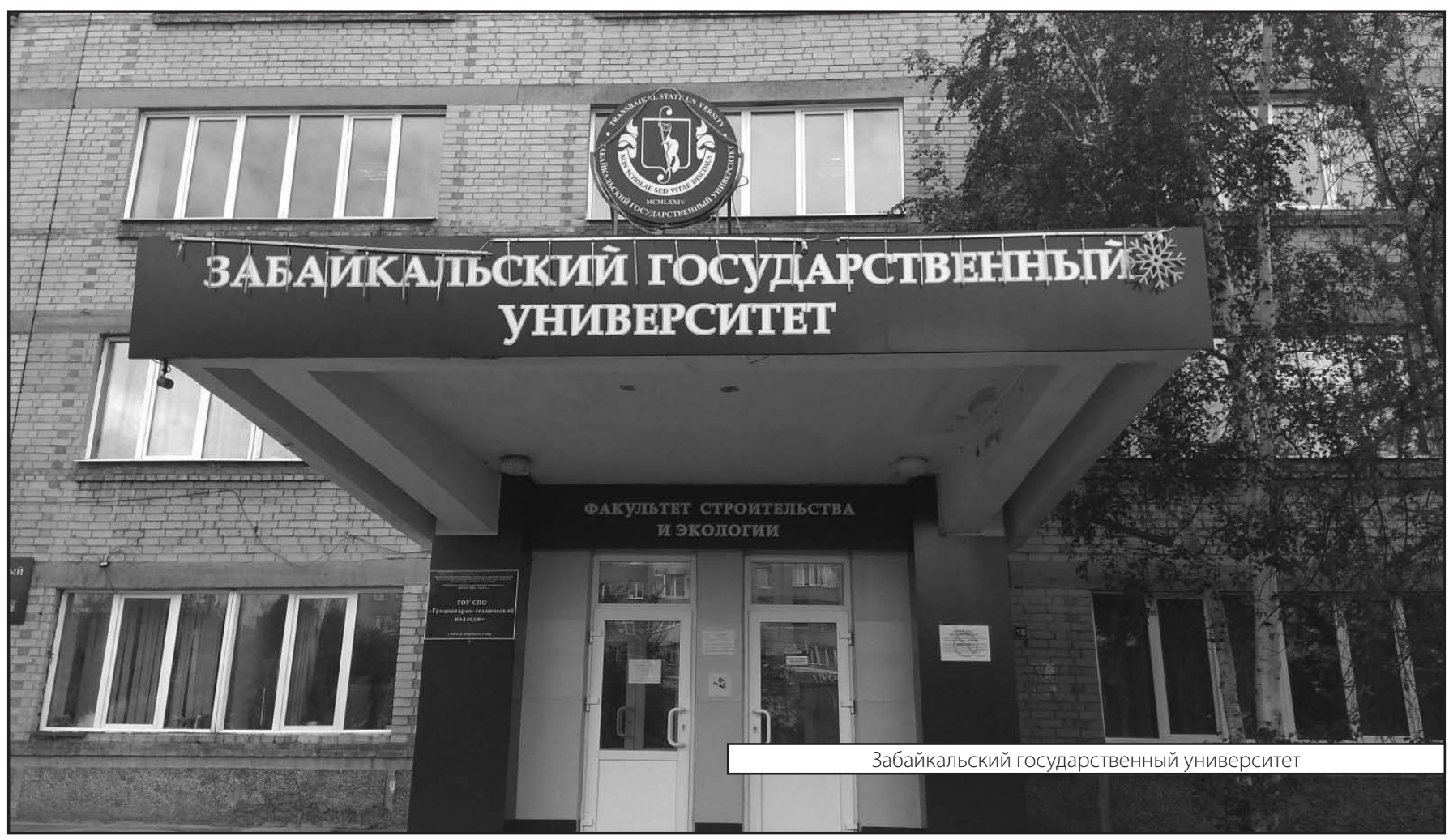

